\title{
Nitrous oxide and methane seasonal variability in the epilimnion of a large tropical meromictic lake (Lake Kivu, East-Africa)
}

\author{
Fleur A. E. Roland ${ }^{1} \cdot$ François Darchambeau $^{1} \cdot$ Cédric Morana $^{2} \cdot$ Alberto V. Borges $^{1}$
}

Received: 3 December 2015/ Accepted: 30 May 2016

(C) Springer International Publishing 2016

\begin{abstract}
We report a data-set of monthly vertical profiles obtained from January 2012 to October 2013, from the surface to $70 \mathrm{~m}$ depth of nitrous oxide $\left(\mathrm{N}_{2} \mathrm{O}\right)$ and dissolved methane $\left(\mathrm{CH}_{4}\right)$ in Lake Kivu, a large and deep meromictic tropical lake (East Africa). Vertical variations of $\mathrm{N}_{2} \mathrm{O}$ were modest, with ranges of 6-9 and $0-16 \mathrm{nmol} \mathrm{L}^{-1}$ in surface and bottom waters, respectively, and occasionally peaks of $\mathrm{N}_{2} \mathrm{O}$ (up to $58 \mathrm{nmol} \mathrm{L}^{-1}$ ) were observed at the oxic-anoxic interface. On the contrary, steep vertical gradients of $\mathrm{CH}_{4}$ were observed with values changing several orders of magnitude from surface $\left(19-103 \mathrm{nmol} \mathrm{L}^{-1}\right)$ to $70 \mathrm{~m}$ $\left(\sim 113,000-520,000 \mathrm{nmol} \mathrm{L}^{-1}\right)$. Seasonal variations of $\mathrm{CH}_{4}$ were caused by annual cycles of mixing and stratification, during the dry and rainy seasons, respectively. This mixing allowed the establishment of a thick oxic layer (maximum $65 \mathrm{~m}$ deep), leading to decreased $\mathrm{CH}_{4}$ concentrations (minimum of $8 \mathrm{nmol} \mathrm{L}^{-1}$ ), presumably due to bacterial $\mathrm{CH}_{4}$ oxidation. During the stratification period, the oxic mixed layer was thinner (minimum $25 \mathrm{~m}$ deep), and an increase of $\mathrm{CH}_{4}$ concentrations in surface waters was observed (maximum of $103 \mathrm{nmol} \mathrm{L}^{-1}$ ), probably due to a lower integrated $\mathrm{CH}_{4}$ oxidation on the water column. Lake Kivu seasonally alternated between a source and a sink for atmospheric $\mathrm{N}_{2} \mathrm{O}$, but on an annual scale was a
\end{abstract}

Electronic supplementary material The online version of this article (doi:10.1007/s00027-016-0491-2) contains supplementary material, which is available to authorized users.

Fleur A. E. Roland

froland@doct.ulg.ac.be

1 Chemical Oceanography Unit, University of Liège, Liège, Belgium

2 Department of Earth and Environmental Sciences, KU Leuven, Louvain, Belgium small source of $\mathrm{N}_{2} \mathrm{O}$ to the atmosphere (on average $0.43 \mu \mathrm{mol} \mathrm{m}{ }^{-2}$ day $^{-1}$ ), while it was a small source of $\mathrm{CH}_{4}$ to the atmosphere throughout the year (on average $86 \mu \mathrm{mol} \mathrm{m}{ }^{-2}$ day $\left.^{-1}\right)$. Vertical and seasonal variations of $\mathrm{N}_{2} \mathrm{O}$ are discussed in terms of nitrification and denitrification, although from the present data-set it is not possible to unambiguously identify the main drivers of $\mathrm{N}_{2} \mathrm{O}$ production.

Keywords Nitrous oxide $\cdot$ Methane $\cdot$ Tropical lake $\cdot$ Lake Kivu

\section{Introduction}

Methane $\left(\mathrm{CH}_{4}\right)$ and nitrous oxide $\left(\mathrm{N}_{2} \mathrm{O}\right)$ are two important greenhouse gases whose global warming potential are respectively 34 and 298 times higher on a 100-year time frame than carbon dioxide $\left(\mathrm{CO}_{2}\right)$ (IPCC 2013). Additionally, $\mathrm{N}_{2} \mathrm{O}$ depletes stratospheric ozone. The concentrations of $\mathrm{CH}_{4}$ and $\mathrm{N}_{2} \mathrm{O}$ in the atmosphere have significantly increased during the 20th century due to human activities, agriculture in particular.

$\mathrm{N}_{2} \mathrm{O}$ in aquatic systems is mainly produced by nitrification and denitrification with optimal temperature estimated to be in the $25-30{ }^{\circ} \mathrm{C}$ range (Saad and Conrad 1993). Hence, an increase of these processes can be expected with increasing temperatures, but $\mathrm{N}_{2} \mathrm{O}$ emissions are also strongly linked to nitrogen and oxygen availability. In this sense, the highest $\mathrm{N}_{2} \mathrm{O}$ emissions from inland waters are reported from systems enriched by fertilizer use in catchment areas or wastewaters (Zhang et al. 2010; Baulch et al. 2011). Indeed, African rivers have been recently shown to be lower $\mathrm{N}_{2} \mathrm{O}$ emitters compared to their temperate counterparts, presumably due to the different 
agricultural practices (i.e., traditional versus fertilizer-intensive) (Borges et al. 2015a).

$\mathrm{CH}_{4}$ in aquatic systems is mostly produced in the anoxic layers of sediments and is transported to the surface by diffusion, mixing, and ebullition. Aerobic and anaerobic $\mathrm{CH}_{4}$ oxidation can take place during the transport, and the fraction that is not oxidized is emitted to the atmosphere. Natural wetlands are known to be the major natural source of $\mathrm{CH}_{4}$ for the atmosphere (175-217 $\mathrm{Tg} \mathrm{CH}_{4}$ year $^{-1}$ ), as well as inland waters (lakes and rivers), since the latter were estimated to emit between $40 \mathrm{Tg} \mathrm{CH}$ year $^{-1}$ (Kirschke et al. 2013) and $103 \mathrm{Tg} \mathrm{CH}_{4}$ year $^{-1}$ (Bastviken et al. 2011). Furthermore, higher emissions of $\mathrm{CH}_{4}$ are expected in tropical inland waters than in temperate and boreal counterparts, in accordance with recent reports (Sawakuchi et al. 2014; Borges et al. 2015a), due to the strong dependence of $\mathrm{CH}_{4}$ production on temperature (Marotta et al. 2014; YvonDurocher et al. 2014). Within the tropical aquatic environments, the Amazon wetlands are the best studied in terms of $\mathrm{CH}_{4}$ dynamics and fluxes (Bartlett et al. 1990; Devol et al. 1990; Engle and Melack 2000; Melack et al. 2004; Bastviken et al. 2010; Borges et al. 2015b). These wetlands consist of flooded forest, floating macrophytes and permanent or temporary floodplain lakes that emit large amounts of $\mathrm{CH}_{4}$ to the atmosphere. Comparatively, tropical upland lakes are much less studied for $\mathrm{CH}_{4}$ and $\mathrm{N}_{2} \mathrm{O}$ dynamics. In addition, data are particularly scarce in large lakes (Holgerson and Raymond 2016). Furthermore, seasonal variations of $\mathrm{CH}_{4}$ and $\mathrm{N}_{2} \mathrm{O}$ fluxes have seldom been described in lakes, and mostly in boreal systems (e.g. Kankaala et al. 2013; Miettinen et al. 2015). Eddy-covariance allows the direct measurement of $\mathrm{CH}_{4}$ and $\mathrm{N}_{2} \mathrm{O}$ fluxes to the atmosphere in lakes (e.g. Podgrajsek et al. 2014; Xiao et al. 2014), although fluxes are usually computed from dissolved concentrations in surface waters using estimates of the gas transfer velocity (e.g. Schubert et al. 2010; Kankaala et al. 2013; Miettinen et al. 2015).

In this study, we report a 2-year time series of monthly measurements of $\mathrm{CH}_{4}, \mathrm{~N}_{2} \mathrm{O}$ and nitrate $\left(\mathrm{NO}_{3}{ }^{-}\right)$concentrations in a large tropical lake (Lake Kivu, East Africa). Lake Kivu is a deep (maximum $485 \mathrm{~m}$ ) meromictic lake characterized by anoxic deep waters rich in dissolved $\mathrm{CH}_{4}$ and nutrients (Degens et al. 1973; Schmid et al. 2005; Tassi et al. 2009). Surface waters are oligotrophic and are characterized by relatively low primary production ranging between 143 and $278 \mathrm{~g} \mathrm{C} \mathrm{m}^{-2}$ year $^{-1}$ (Darchambeau et al. 2014, Morana et al. 2014), and have been shown to be net autotrophic (Morana et al. 2014), yet they emit carbon dioxide $\left(\mathrm{CO}_{2}\right)$ to the atmosphere due to geogenic $\mathrm{CO}_{2}$ inputs from deep waters (Borges et al. 2014). A first study of $\mathrm{CH}_{4}$ dynamics in Lake Kivu showed very low $\mathrm{CH}_{4}$ concentrations in surface waters (Borges et al. 2011), presumably due to intense $\mathrm{CH}_{4}$ oxidation as $\mathrm{CH}_{4}$ is transported upwards (Borges et al. 2011; Pasche et al. 2011; Morana et al. 2015a). The first study of $\mathrm{CH}_{4}$ in surface waters (Borges et al. 2011) was based on a coarse seasonal coverage (only four cruises), focused on surface waters and did not describe the vertical variability of $\mathrm{CH}_{4}$ in the top $100 \mathrm{~m}$. While most previous studies have focused on carbon cycling in Lake Kivu, nitrogen cycling has received much less attention. The aim of this study is to describe seasonal variations of $\mathrm{CH}_{4}$ and $\mathrm{N}_{2} \mathrm{O}$ in the epilimnion of a tropical lake and attempt to unravel the underlying processes. Moreover, as a large scale industrial extraction of $\mathrm{CH}_{4}$ from the deep layers of Lake Kivu is planned (Nayar 2009), it is important to establish the baseline of ecological and biogeochemical settings to monitor, understand and quantify the consequences of this industrial extraction of $\mathrm{CH}_{4}$. Information on the temporal variability of the vertical structure in the top $100 \mathrm{~m}$ is required to achieve a comprehensive description of base-line conditions of $\mathrm{CH}_{4}$ in Lake Kivu prior to industrial extraction.

The present study focuses on one station in the Southern Basin of the lake (Ishungu station), and thus provides temporally resolved data compared to previous reports of $\mathrm{CH}_{4}$ concentrations focusing on spatial variations in surface waters by Borges et al. (2011). The present paper also complements the work of Morana et al. (2015b) based on the same two-year sampling at Ishungu, which mainly focused on the biogeochemistry of organic matter.

\section{Materials and methods}

\section{Study site}

Lake Kivu is located at the border between Rwanda and Democratic Republic of the Congo (DRC) $\left[2.50^{\circ} \mathrm{S} 1.59^{\circ} \mathrm{S}\right.$ $\left.29.37^{\circ} \mathrm{E} 28.83^{\circ} \mathrm{E}\right]$. Sampling was carried out every month from late January 2012 to October 2013, at one station in the Southern Basin of the Lake (Ishungu station; $-2.3374^{\circ} \mathrm{N}, 28.9775^{\circ} \mathrm{E}$; Fig. 1).

\section{Physico-chemical parameters and sampling}

Vertical profiles of temperature, conductivity and oxygen $\left(\mathrm{O}_{2}\right)$ were obtained with a Hydrolab DS4 multiparameter probe. Water was collected with a vertical 7L Niskin bottle (Hydro-Bios) every $5 \mathrm{~m}$ from the surface to $70 \mathrm{~m}$.

\section{Water column chemical analyses}

Samples for $\mathrm{N}_{2} \mathrm{O}$ and $\mathrm{CH}_{4}$ concentrations were collected in $50 \mathrm{~mL}$ glass serum bottles from the Niskin bottle through a silicon tube connected to the outlet, left to overflow, poisoned with $100 \mu \mathrm{L}$ of saturated $\mathrm{HgCl}_{2}$ and immediately 


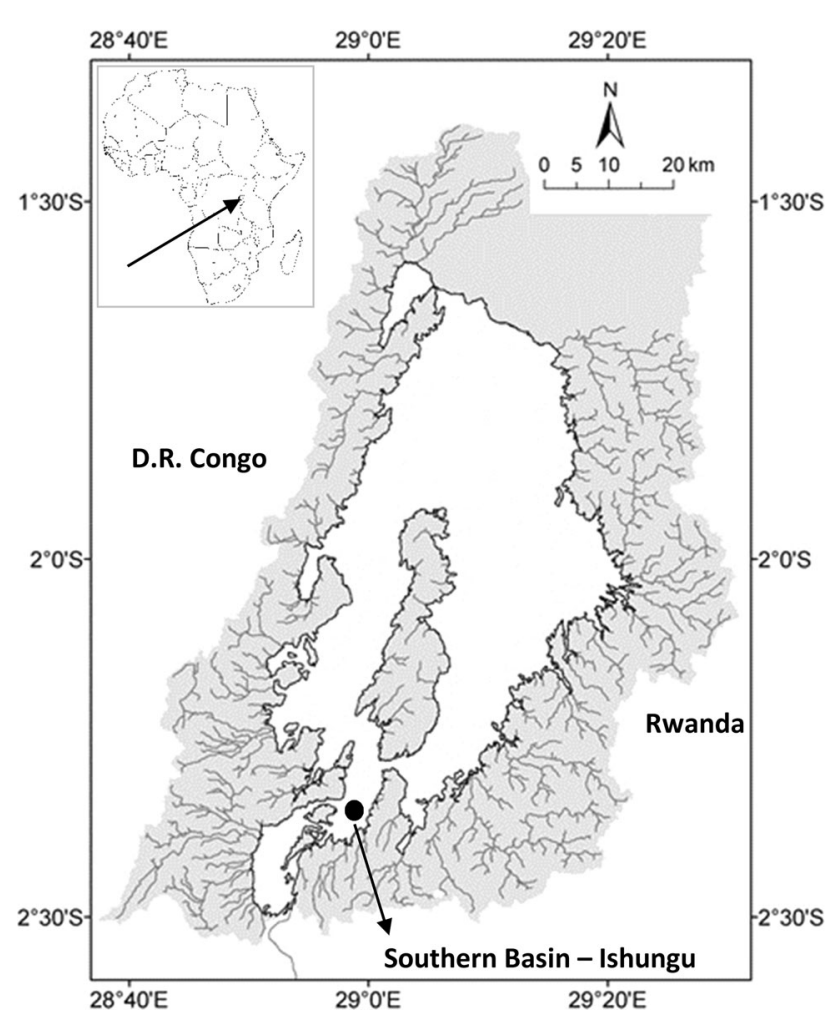

Fig. 1 Map of Lake Kivu, showing sampling site in the Southern Basin

sealed with butyl stoppers and aluminium caps. $\mathrm{CH}_{4}$ and $\mathrm{N}_{2} \mathrm{O}$ concentrations were determined via the headspace equilibration technique $\left(20 \mathrm{~mL} \mathrm{~N}_{2}\right.$ headspace in $50 \mathrm{~mL}$ serum bottles) and measured by gas chromatography (GC) (Weiss 1981) with electron capture detection (ECD) for $\mathrm{N}_{2} \mathrm{O}$ and with flame ionization detection (FID) for $\mathrm{CH}_{4}$. The SRI 8610C GC-ECD-FID was calibrated with certified $\mathrm{CH}_{4}: \mathrm{CO}_{2}: \mathrm{N}_{2} \mathrm{O}: \mathrm{N}_{2}$ mixtures (Air Liquide, Belgium) of 1, 10, 30 and $509 \mathrm{ppm} \mathrm{CH}_{4}$ and of 0.2, 2.0 and $6.0 \mathrm{ppm} \mathrm{N}_{2} \mathrm{O}$. Concentrations were computed using the solubility coefficients of Yamamoto et al. (1976) and Weiss and Price (1980), for $\mathrm{CH}_{4}$ and $\mathrm{N}_{2} \mathrm{O}$, respectively. The precision of measurements was \pm 3.9 and $\pm 3.2 \%$ for $\mathrm{CH}_{4}$ and $\mathrm{N}_{2} \mathrm{O}$, respectively.

When preparing the headspaces, excess water was collected to quantify $\mathrm{NO}_{3}{ }^{-}$and $\mathrm{NH}_{4}{ }^{+}$concentrations by spectrophotometry. $\mathrm{NO}_{3}{ }^{-}$were determined after vanadium reduction to nitrite $\left(\mathrm{NO}_{2}{ }^{-}\right)$and quantified under this form with a Multiskan Ascent Thermo Scientific multi-plates reader (APHA 1998; Miranda et al. 2001). $\mathrm{NH}_{4}{ }^{+}$were quantified according to the dichloroisocyanurate-salicylatenitroprussiate colorimetric method (Westwood 1981), using a $5-\mathrm{cm}$ light path on a spectrophotometer Thermo Spectronic Genesys 10vis. The detection limits for these methods were 0.15 and $0.3 \mu \mathrm{mol} \mathrm{L}{ }^{-1}$ for $\mathrm{NO}_{3}{ }^{-}$and $\mathrm{NH}_{4}{ }^{+}$, respectively.

\section{$\mathrm{CH}_{4}$ and $\mathrm{N}_{2} \mathrm{O}$ flux calculations}

$\mathrm{CH}_{4}$ and $\mathrm{N}_{2} \mathrm{O}$ fluxes with respect to the atmosphere were calculated based on temperature, $\mathrm{CH}_{4}$ and $\mathrm{N}_{2} \mathrm{O}$ concentrations, and the gas transfer velocity computed from wind speed according to the Cole and Caraco (1998) relationship. By convention, a positive flux value corresponds to a gas transfer from the water to the atmosphere, and, conversely, a negative flux corresponds to a gas transfer from the atmosphere to the water. Wind speeds were obtained from the National Centers for Environmental Prediction (NCEP) gridded daily product (grid point $-0.952^{\circ} \mathrm{N}$, $30.000^{\circ} \mathrm{E}$ ). These values were adjusted to fit field measurements from a meteorological station of the Institut Supérieur Pédagogique (ISP) of Bukavu. The ISP wind values were adjusted by the addition of $2 \mathrm{~m} \mathrm{~s}^{-1}$ to account for differences in wind speed between lake and inland where the station is located as suggested by Thiery et al. (2014).

\section{Schmidt Stability Index calculations}

Schmidt Stability Index (SSI) defines the thermal stability of the water column over a certain depth and expresses the amount of energy needed for its full mixing over that depth (Schmidt 1928). SSI from the surface to $65 \mathrm{~m}$ was calculated from density vertical gradients according to Schmidt (1928), and density was computed from temperature and salinity derived from conductivity according to Schmid and Wüest (2012).

\section{Results}

For both years, SSI (Fig. 2a) and temperature variability (Fig. 2b) showed one mixing period, from July to October (dry season), with a maximum mixing in September, while the water column was stratified the rest of the year (rainy season). Mixing periods did not co-occur with higher wind speeds (Fig. 2a), which were observed a few weeks before the mixing. The location of the oxycline (Fig. 2c) followed the seasonal cycling of mixing and stratification, and ranged from 35 to $70 \mathrm{~m}$ depth during the rainy and dry seasons, respectively. Deep waters (from $70 \mathrm{~m}$ ) remained anoxic throughout the year, while surface waters (at $5 \mathrm{~m}$ ) were well oxygenated (oxygen concentrations range 122-243 $\mu \mathrm{mol} \mathrm{L}^{-1}$ ). $\mathrm{N}_{2} \mathrm{O}$ profiles showed on various occasions higher concentration peaks (maximum peak of $52 \mathrm{nmol} \mathrm{L^{-1 }}$ ) in the oxycline, while concentrations remained relatively low in surface waters (from 6.6 to $9.3 \mathrm{nmol} \mathrm{L}^{-1}$, at $5 \mathrm{~m}$ ) and at $70 \mathrm{~m}$ (from 0.1 to $16.4 \mathrm{nmol}$ $\mathrm{L}^{-1}$ ) (Fig. 2d). The maximum peaks of $\mathrm{N}_{2} \mathrm{O}$ were usually observed below the maximum peaks of $\mathrm{NO}_{3}{ }^{-}$ 
Fig. 2 Seasonal profiles of (a) wind speed $\left(\mathrm{m} \mathrm{s}^{-1}\right)$ and Schmidt Stability Index (SSI; J), and seasonal and vertical depth profiles of $\mathbf{b}$ temperature $\left({ }^{\circ} \mathrm{C}\right)$, c $\mathrm{O}_{2}\left(\mu \mathrm{mol} \mathrm{L}{ }^{-1}\right), \mathbf{d ~ N}_{2} \mathrm{O}(\mathrm{nmol}$ $\left.\mathrm{L}^{-1}\right)$, e $\mathrm{NO}_{3}^{-}\left(\mu \mathrm{mol} \mathrm{L}{ }^{-1}\right)$, f $\mathrm{NH}_{4}^{+}\left(\mu \mathrm{mol} \mathrm{L}{ }^{-1}\right)$ and $\mathbf{g ~ l o g}$ $\mathrm{CH}_{4}\left(\mathrm{nmol} \mathrm{L}^{-1}\right)$ from late January 2012 to October 2013, and $\mathbf{g ~ N H _ { 4 }}{ }^{+}\left(\mu \mathrm{mol} \mathrm{L}{ }^{-1}\right)$ from late October 2012 to October 2013. White dotted line is the oxic-anoxic transition zone
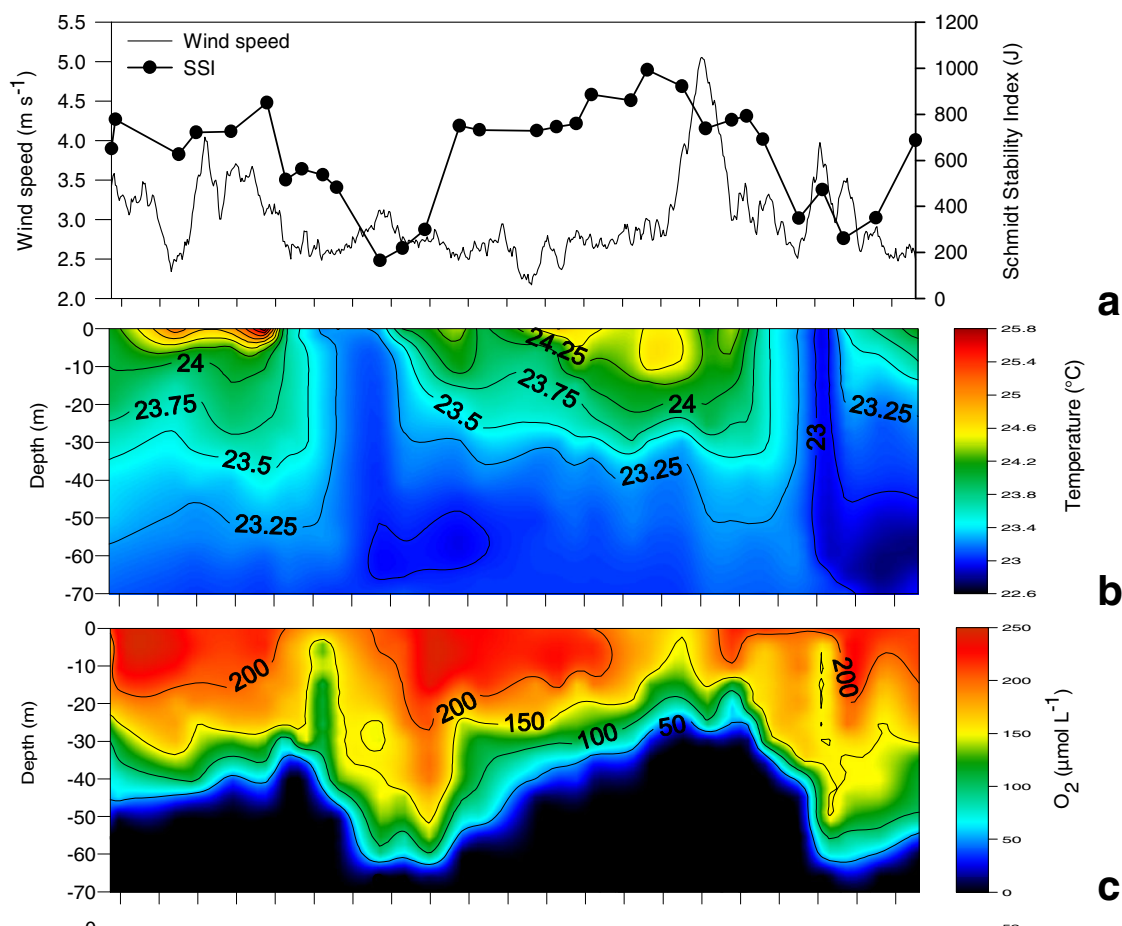

b
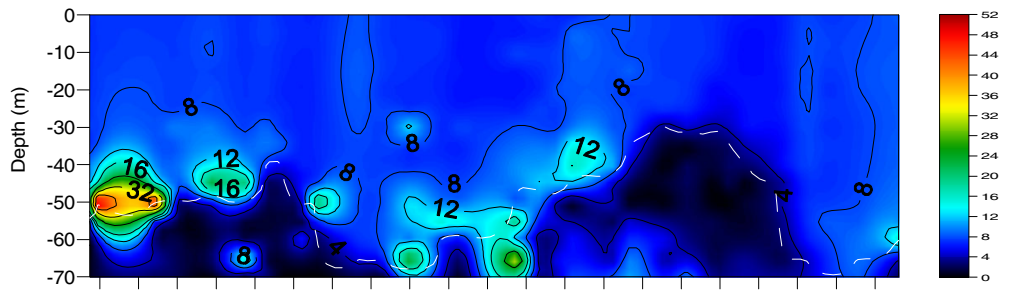

c
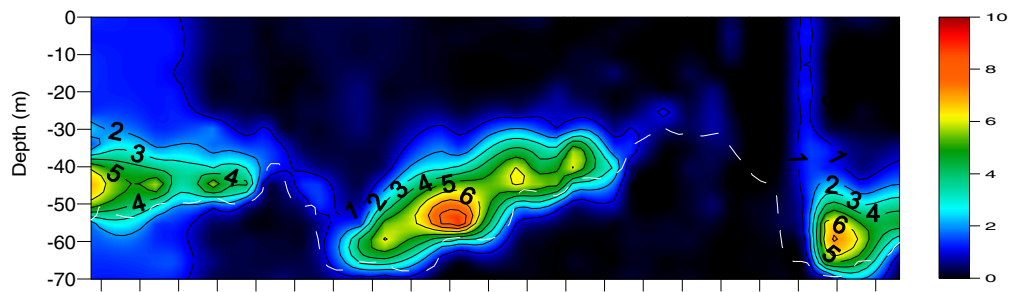

d
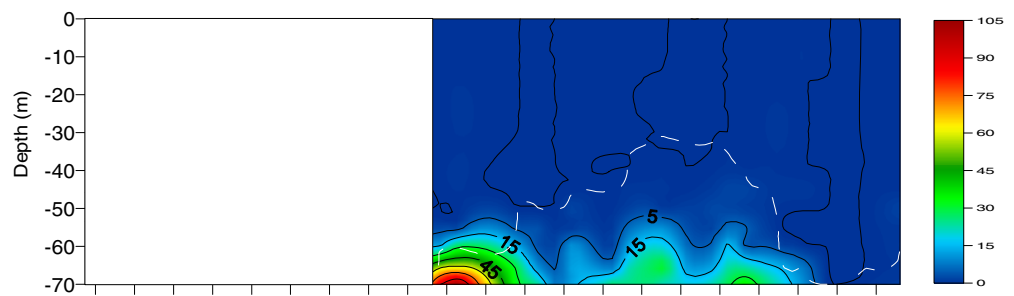

e

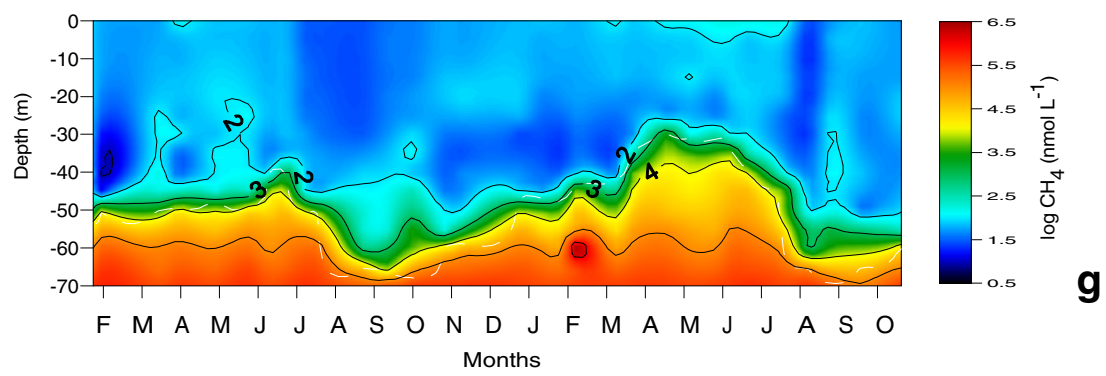


concentrations (Fig. 2e), and sometimes with a time delay. Three $\mathrm{NO}_{3}{ }^{-}$accumulation zones (nitraclines) were observed: from late January to June 2012, from late August to late December 2012, and from late August to September 2013. Maximum $\mathrm{NO}_{3}{ }^{-}$concentrations associated to these nitraclines ranged between 7 and $10 \mu \mathrm{mol} \mathrm{L}{ }^{-1}$. $\mathrm{NH}_{4}^{+}$ concentrations tended to be higher in anoxic waters, with concentrations up to $110 \mu \mathrm{mol} \mathrm{L}^{-1}$ at $70 \mathrm{~m}$ depth (Fig. 2f). In oxic surface waters (at $5 \mathrm{~m}$ ), $\mathrm{CH}_{4}$ concentrations (Fig. $2 \mathrm{~g}$ ) remained low throughout the year and ranged between 19 and $103 \mathrm{nmol} \mathrm{L}{ }^{-1}$. At $70 \mathrm{~m}, \mathrm{CH}_{4}$ concentrations were higher and ranged from $\sim 113,000$ to $520,000 \mathrm{nmol} \mathrm{L}^{-1}$.

$\mathrm{N}_{2} \mathrm{O}$ concentrations at $5 \mathrm{~m}$ depth showed no correlation to SSI (Fig. 3a). The seasonal variations of $\mathrm{NO}_{3}{ }^{-}$concentrations and SSI were linked (Fig. 3b): when vertical mixing occurred (low SSI; August and September 2012 and 2013), $\mathrm{NO}_{3}{ }^{-}$concentrations began to increase to reach their maximum 1-2 months later. Contrary to $\mathrm{N}_{2} \mathrm{O}, \mathrm{CH}_{4}$ concentrations in surface waters followed the pattern of the SSI (Fig. 3c) and were significantly correlated $\left(R^{2}=0.23\right.$, $p<0.01, n=29$ ); minima of $\mathrm{CH}_{4}$ concentrations co-occurred with SSI minima.

$\mathrm{N}_{2} \mathrm{O}$ fluxes (Fig. 3d) showed large fluctuations during the studied period. Negative fluxes were observed in January 2012, July-August 2012, November 2012-January 2013 and June-August 2013 (ranging between -2.2 and $-0.001 \mu \mathrm{mol} \mathrm{m}{ }^{-2}$ day $^{-1}$ ). The rest of the year, $\mathrm{N}_{2} \mathrm{O}$ fluxes were positive, with a maximum flux of $3.5 \mu \mathrm{mol} \mathrm{m} \mathrm{m}^{-2}$ day ${ }^{-1}$ in February 2013. The average $\mathrm{N}_{2} \mathrm{O}$ flux for both years of sampling was $0.4 \mu \mathrm{mol} \mathrm{m}{ }^{-2} \mathrm{day}^{-1}$. The highest $\mathrm{CH}_{4}$ flux to the atmosphere was in June 2013 $\left(222 \mu \mathrm{mol} \mathrm{m} \mathrm{m}^{-2} \mathrm{day}^{-1}\right)$ and the lowest was in August 2013 $\left(24 \mu \mathrm{mol} \mathrm{m}{ }^{-2}\right.$ day $^{-1}$ ) (Fig. 3e). The average $\mathrm{CH}_{4}$ flux for the 2 years of sampling was $85 \mu \mathrm{mol} \mathrm{m} \mathrm{m}^{-2} \mathrm{~d}^{-1}$. The seasonal differences in $\mathrm{CH}_{4}$ fluxes were very low (rainy season mean flux of $96 \mu \mathrm{mol} \mathrm{m}{ }^{-2}$ day $^{-1}$ and dry season mean flux of $64 \mu \mathrm{mol} \mathrm{m} \mathrm{m}^{-2} \mathrm{~d}^{-1}$ ).

\section{Discussion}

The alternation between stratification of the water column in rainy season and mixing events in dry season is a typical behavior for Lake Kivu (Schmid and Wüest 2012). Mixing periods did not co-occur with higher wind speeds, which were observed a few weeks before the mixing. This strongly suggests that wind stress is not the main factor for the mixing of the water column in Lake Kivu contrary to what is reported for the nearby Lake Tanganyika (Thiery et al. 2014). Indeed, increased heat fluxes due to evaporation related to changes in solar radiation and air humidity
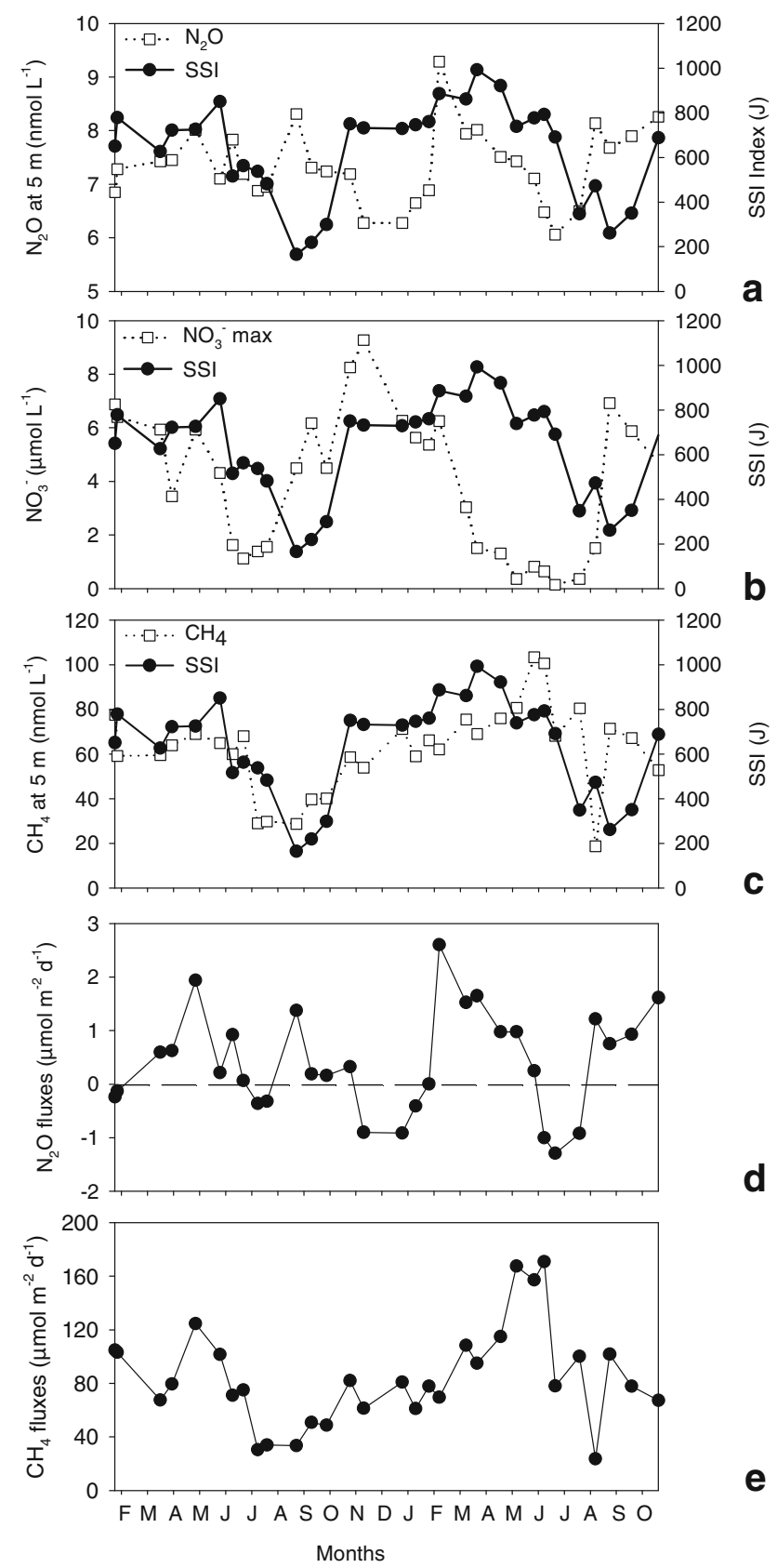

Fig. 3 a-c Comparison between Schmidt Stability Index (SSI; J; black circles) and $\mathrm{N}_{2} \mathrm{O}$ concentrations ( $\mathrm{nmol} \mathrm{L}^{-1}$; white squares) at $5 \mathrm{~m}$ depth, maximum $\mathrm{NO}_{3}{ }^{-}$concentrations ( $\mu \mathrm{mol} \mathrm{L} \mathrm{L}^{-1}$; white squares) and $\mathrm{CH}_{4}$ concentrations (nmol L ${ }^{-1}$; white squares) at $5 \mathrm{~m}$ depth, respectively; d, e atmospheric $\mathrm{N}_{2} \mathrm{O}$ and $\mathrm{CH}_{4}$ fluxes $\left(\mu \mathrm{mol} \mathrm{m} \mathrm{m}^{-2}\right.$ $\mathrm{d}^{-1}$ ), respectively, from late January 2012 to October 2013

is the main driver of mixing during the dry season in Lake Kivu (Thiery et al. 2014).

$\mathrm{N}_{2} \mathrm{O}$ fluxes fluctuated widely during the two-year sampling, and we observed both positive and negative fluxes, indicating that Lake Kivu acted as a sink and a source for atmospheric $\mathrm{N}_{2} \mathrm{O} . \quad \mathrm{N}_{2} \mathrm{O}$ fluxes are driven by 
nitrification/denitrification processes in the water column. Nitrification is considered as an important source of $\mathrm{N}_{2} \mathrm{O}$, while denitrification, by consuming $\mathrm{N}_{2} \mathrm{O}$ to produce $\mathrm{N}_{2}$, is often considered as a sink. However, in the oxic-anoxic transition zone, when $\mathrm{O}_{2}$ level is low (below $6 \mu \mathrm{mol} \mathrm{L}^{-1}$ ), the last step of denitrification, i.e. $\mathrm{N}_{2} \mathrm{O}$ reduction to $\mathrm{N}_{2}$, can be inhibited while the $\mathrm{NO}_{3}{ }^{-}$reduction to $\mathrm{N}_{2} \mathrm{O}$ step can still occur leading to a net $\mathrm{N}_{2} \mathrm{O}$ production (Seitzinger et al. 2006). A few factors allow us to suggest the occurrence of these two processes in the water column of Lake Kivu. $\mathrm{N}_{2} \mathrm{O}$ profiles, showed on some occasions concentrations peaks in the oxycline, a common feature for meromictic lakes (Mengis et al. 1997). Nitrification was evidenced by the presence of $\mathrm{NO}_{3}{ }^{-}$accumulation zones (nitraclines) during the rainy season, which in turn can sustain denitrification in the anoxic water column. Nitraclines are the result of vertical mixing of superficial waters occurring during the dry season. During this vertical mixing event, oxygen penetrated deep in the water column, down to the bottom of the mixolimnion, where reduced species such as $\mathrm{NH}_{4}{ }^{+}$are abundant. $\mathrm{NH}_{4}{ }^{+}$thus became available for phytoplankton and nitrifying bacteria and archaea growth. Accordingly, nitrification led to the establishment of a nitracline that appeared with some delay after the initial mixing event that brought $\mathrm{NH}_{4}^{+}$in contact with oxic waters. The fact that maximums of $\mathrm{NO}_{3}{ }^{-}$concentrations were observed 1-2 months after the mixing event (reflected by SSI) can be explained by the time required for the nitrifier community to develop and for $\mathrm{NO}_{3}{ }^{-}$to accumulate in the water column.

In late January 2012, high $\mathrm{N}_{2} \mathrm{O}$ values were observed in oxic waters (e.g., $47.5 \mathrm{~m}$ ) corresponding to maximum $\mathrm{NO}_{3}{ }^{-}$values. The presence of higher abundances of a $\mathrm{NO}_{2}{ }^{-}$-oxidizing bacteria (Nitrospira) (İnceoğlu et al. 2015a) at those depths strongly suggests the occurrence of nitrification. Nitrification rates in Lake Kivu have never been directly quantified, but the study of Llirós et al. (2010) showed the presence of a nitrifying archaeal community in the oxycline, suggesting a potentially important role of archaeal nitrification. In late January 2012, a diversified archaeal community was also observed (İnceoğlu et al. 2015a). The Marine Group I (Thaumarcheota), which are ammonia oxidizing archaea (AOA), was well represented in the superficial oxic waters, where they represented the whole archaeal community at some depths. AOA are thought to be dominant over ammonia oxidizing bacteria (AOB) in most environments (Stieglmeier et al. 2014), and they seem to be predominant in oligotrophic environments (Stahl and De La Torre 2012), such as the oxic waters of Lake Kivu (Llirós et al. 2010, İnceoğlu et al. 2015a). However, some $\mathrm{N}_{2} \mathrm{O}$ peaks were clearly located in anoxic waters, as in late January 2012 which suggest the involvement of other processes in $\mathrm{N}_{2} \mathrm{O}$ production, such as denitrification. Pyrosequencing data obtained by İnceoğlu et al. (2015a) showed the presence of Betaproteobacteria, which were highly abundant at the oxic-anoxic interface. This class includes in particular two well-known denitrifiers, Denitratisoma sp. and Thiobacillus sp., which can potentially be responsible for denitrification in Lake Kivu, and some bacterial nitrifiers, such as Nitrosomonas sp. As nitrification, denitrification has never been quantified in Lake Kivu, but conditions for the occurrence of this process are present in rainy season, since non-negligible $\mathrm{NO}_{3}{ }^{-}$ concentrations are often observed at the oxic-anoxic interface.

Deep isoclines of $\mathrm{CH}_{4}$ concentrations followed the bottom of the oxycline, strongly suggesting the occurrence of $\mathrm{CH}_{4}$ oxidation in the water column of Lake Kivu, as recently evidenced by mass balance (Borges et al. 2011; Pasche et al. 2011) or stable isotopic signature and processes measurement studies (Morana et al. 2015a, b). İnceoğlu et al. (2015a) observed the presence of an important community of aerobic and anaerobic methanotrophs (mainly Methylomonas-related operational taxonomic units and anaerobic methanotrophic archaea (ANME), respectively) in the Southern Basin (Ishungu Basin) of Lake Kivu, giving support to the occurrence of intense $\mathrm{CH}_{4}$ oxidation in the water column. They also observed archaeal methanogens which suggested that methanogenesis could occur in the water column, whereas previous research on $\mathrm{CH}_{4}$ dynamics assumed that sediments were the only source of $\mathrm{CH}_{4}$ in Lake Kivu (Pasche et al. 2011). In aquatic environments, $\mathrm{CH}_{4}$ is mainly produced in sediments but some studies also reported $\mathrm{CH}_{4}$ production in anoxic waters (e.g. Winfrey and Zeikus 1979; Iversen et al. 1987; Borrel et al. 2011; Crowe et al. 2011).

During our study, $\mathrm{CH}_{4}$ concentrations at $5 \mathrm{~m}$ were significantly correlated with SSI and were higher during the rainy season (high SSI) than during the dry season (low SSI). During the rainy season, the oxic layer became thinner and anoxic waters rich in $\mathrm{CH}_{4}$ were closest to the surface, limiting $\mathrm{CH}_{4}$ losses by aerobic oxidation. On the contrary, during the dry season the oxic layer deepened and integrated aerobic $\mathrm{CH}_{4}$ oxidation on the oxic water column might be higher leading to lower $\mathrm{CH}_{4}$ concentrations in surface waters. In general, the seasonal amplitude of $\mathrm{CH}_{4}$ concentrations in surface waters was low $\left(84 \mathrm{nmol} \mathrm{L}^{-1}\right)$ compared to higher latitude lakes (range 100-65,000 nmol L ${ }^{-1}$; Supplemental Table 1). This might be explained by the large $\mathrm{CH}_{4}$ accumulation during winter below the frozen lake surface and by more frequent lake overturn which mixes deep and surface waters, a typical process in holomictic lakes unlike Lake Kivu which is permanently stratified. Seasonal changes in oxic and anoxic conditions also contribute to seasonal amplitudes, as anoxia 
can develop through the water column below frozen lake surface leading to very high $\mathrm{CH}_{4}$ concentrations. Seasonal variations of oxic layer thickness was highlighted in the present case of Lake Kivu as the driver of seasonal variations.

The importance of $\mathrm{CH}_{4}$ oxidation in the water column of Lake Kivu may explain low $\mathrm{CH}_{4}$ fluxes observed. Only diffusive $\mathrm{CH}_{4}$ fluxes are reported here, since ebullitive fluxes are supposed to be negligible due to the deepness of Lake Kivu and absence of extensive shallow zones (Borges et al. 2011), that according to Natchimuthu et al. (2015) contribute to strong spatial heterogeneity in $\mathrm{CH}_{4}$ emissions from small shallow lakes. It should be noted that the parameterization used in the present work (Cole and Caraco 1998) might underestimate the computations of gas transfer velocities due to the large size (Read et al. 2012; Schilder et al. 2013) and diurnal temperature variations (Polsenaere et al. 2013; Podgrajsek et al. 2014) in Lake Kivu which have been reported to be large (Borges et al. 2012). Anyway, the Southern Basin of Lake Kivu was a source of $\mathrm{CH}_{4}$ for the atmosphere throughout the year, but was a very small source of $\mathrm{CH}_{4}$ for the atmosphere compared to other lakes globally, by an order of magnitude. The overall $\mathrm{CH}_{4}$ emission for lakes is $3281 \mu \mathrm{mol} \mathrm{m} \mathrm{m}^{-2}$ day $^{-1}$ globally, and $7779 \mu \mathrm{mol} \mathrm{m}{ }^{-2}$ day $^{-1}$ for tropical systems according to Bastviken et al. (2011), whereas the value for Lake Kivu was $85 \mu \mathrm{mol} \mathrm{m}{ }^{-2}$ day ${ }^{-1}$. Besides $\mathrm{CH}_{4}$ oxidation, the low $\mathrm{CH}_{4}$ emission can also be linked to the morphometric characteristics of Lake Kivu: large, deep and meromictic. Indeed, despite the fact that deep waters of Lake Kivu are extremely rich in $\mathrm{CH}_{4}\left(60 \mathrm{~km}^{3}\right.$ of $\mathrm{CH}_{4}$ are dissolved in deep waters; Schmid et al. 2005), the stratification of the water column (especially the main chemocline located at $250 \mathrm{~m}$; Pasche et al. 2009) prevents the upward rise of this $\mathrm{CH}_{4}$ towards surface waters. $\mathrm{CH}_{4}$ from the upper part of the monimolimnion can only rise to surface waters by slow diffusion throughout the year, and by seasonal mixing of the epilimnion, which erodes the upper part of the monimolimnion (Borges et al. 2011; Pasche et al. 2011). Thus, due to this water column structure and an important bacterial $\mathrm{CH}_{4}$ oxidation, surface waters of Lake Kivu have extremely low $\mathrm{CH}_{4}$ concentrations when compared with bottom waters, which limits the $\mathrm{CH}_{4}$ emissions to the atmosphere. Accordingly, the seasonal variations of $\mathrm{CH}_{4}$ fluxes were estimated to be very low (rainy season mean flux of $96 \mu \mathrm{mol} \mathrm{m}^{-2}$ day $^{-1}$ and dry season mean flux of $64 \mu \mathrm{mol} \mathrm{m}{ }^{-2}$ day $^{-1}$ ).

This study focused on one station in the Southern Basin of Lake Kivu. However, due to the large size of Lake Kivu, some spatial heterogeneity can be observed. Numerous studies underline the importance of spatial variations of $\mathrm{CH}_{4}$ emissions (e.g. Bastviken et al. 2004; Hofmann 2013; Schilder et al. 2013; Natchimuthu et al. 2015). During our study, 5 profiles were collected in the Northern Basin of the lake, which has a larger surface and is more exposed to wind. Available data (Supplemental Fig. 1) suggest that the station of Ishungu, in the Southern Basin, is not representative of the whole lake, since large differences in stratifications can be observed. Indeed, the Northern Basin showed deeper mixings and more pronounced gradients, which clearly influence vertical profiles of $\mathrm{CH}_{4}$ and $\mathrm{N}_{2} \mathrm{O}$. The differences between the depths of the oxyclines impacted $\mathrm{CH}_{4}$ concentrations in deep waters, and $\mathrm{N}_{2} \mathrm{O}$ profiles were also quite different. Stratification clearly influences bacterial and archaeal communities; for example, İnceoğlu et al. (2015a) estimated that the relative abundances of Betaproteobacteria were $28 \%$ and $46 \%$ for the Northern and Southern Basins, respectively. Moreover, due to the large size of the lake, we cannot expect that wind velocities in the Northern Basin are the same as those in the Southern Basin.

However, $\mathrm{CH}_{4}$ concentrations in surface waters (at $5 \mathrm{~m}$ ) were quite similar in both stations $\left(R^{2}=0.625\right)$, and means of $\mathrm{N}_{2} \mathrm{O}$ concentrations in surface waters were 7 and $8 \mathrm{nmol} \mathrm{L}^{-1}$ in the Northern and Southern Basins, respectively. This suggests that $\mathrm{CH}_{4}$ and $\mathrm{N}_{2} \mathrm{O}$ fluxes in the Northern Basin are probably of the same order of magnitude as in the Southern Basin. Also, based on $\mathrm{O}_{2}$ and temperature vertical profiles data obtained from March 2007 to April 2009 at nine stations in the lake (Borges et al. 2011), we can assume that the station of Ishungu is well representative of the Southern Basin, and even of the Western Basin and of the south part of the Eastern Basin (Supplemental Fig. 2 and Supplemental Table 2).

This study is, to our knowledge, the first one to report detailed data and long time-series of $\mathrm{CH}_{4}$ and $\mathrm{N}_{2} \mathrm{O}$ in a large tropical lake. Our data confirms that Lake Kivu has a very low $\mathrm{CH}_{4}$ emission to the atmosphere despite having extremely large quantities of $\mathrm{CH}_{4}$ in the bottom waters. Yet, $\mathrm{CH}_{4}$ in surface waters showed seasonal variations that relate mixing events and deepening of the mixolimnion. The emissions of $\mathrm{N}_{2} \mathrm{O}$ to the atmosphere were also modest although vertical profiles of $\mathrm{N}_{2} \mathrm{O}$ show dynamic patterns with marked sources and sinks of $\mathrm{N}_{2} \mathrm{O}$ in the water column. We were not able to determine from vertical profiles of $\mathrm{N}_{2} \mathrm{O}$ concentrations if nitrification or denitrification or a combination of both was the process leading to $\mathrm{N}_{2} \mathrm{O}$ accumulation in the water column that occurred at the oxicanoxic interface. This suggests that process orientated studies quantifying denitrification and nitrification are required to further unravel $\mathrm{C}$ and $\mathrm{N}$ dynamics in this large meromictic tropical lake, as well as additional data on bacterial diversity and activity that are limited to two samplings (İnceoğlu et al. 2015a, b). The present data-set is the first to give a detailed description of the seasonal variations of the vertical distribution of $\mathrm{CH}_{4}$ and $\mathrm{N}_{2} \mathrm{O}$ in upper Lake Kivu $(<100 \mathrm{~m})$. Any deviation from the 
reported patterns will be indicative of changes in $\mathrm{CH}_{4}$ and $\mathrm{N}_{2} \mathrm{O}$ cycling and potential emission to the atmosphere related to the $\mathrm{CH}_{4}$ extraction (Nayar 2009). Once the $\mathrm{CH}_{4}$ is extracted in surface plants, the water is re-injected above the extraction point (to avoid diluting the resource). This re-injection could lead to the enrichment in $\mathrm{NH}_{4}^{+}$and changes in $N$ cycling which could enhance $\mathrm{N}_{2} \mathrm{O}$ emissions to the atmosphere. The water re-injection might lead to changes in water column stratification that as we have shown allows an effective removal of upward diffusing $\mathrm{CH}_{4}$ by bacterial $\mathrm{CH}_{4}$ oxidation. A decrease in this water column $\mathrm{CH}_{4}$ sink would lead to enhanced $\mathrm{CH}_{4}$ emissions to the atmosphere.

Acknowledgments We thank Boniface Kaningini, Pascal Isumbisho, Georges Alunga, Fabrice Muvundja and Pascal Masilya (Institut Supérieur Pédagogique, Bukavu, DRC) for logistic support for the monitoring, and providing the meteorological data, Professor JeanPierre Thomé (University of Liège, ULg) for access to the multi-plate reader, and Marc-Vincent Commarieu (ULg) for help in analyses. This study was funded by the Belgian Federal Science Policy Office (BELSPO, Belgium) under the EAGLES (East African Great lake Ecosystem Sensitivity to Changes, SD/AR/02A) project, by the Fonds National de la Recherche Scientifique (FNRS) under the MICKI (Microbial diversity and processes in Lake Kivu, 1715859) project, and contributes to the European Research Council (ERC) starting grant AFRIVAL (African river basins: Catchment-scale carbon fluxes and transformations, 240002). A.V.B is a senior research associated to the FNRS. F.A.E.R received a PhD grant from FNRS (Fonds pour la Formation à la Recherche dans l'Industrie et dans l'Agriculture).

\section{References}

APHA (1998) Standard methods for the examination of water and wastewater. American Public Health Association, USA

Bartlett KB, Crill PM, Bonassi JA, Richey JE, Harriss RC (1990) Methane flux from the Amazon River floodplain: emissions during rising water. J Geophys Res 95:16773-716788

Bastviken D, Cole J, Pace M, Tranvik L (2004) Methane emissions from lakes: dependence of lake characteristics, two regional assessments, and a global estimate. Glob Biogeochem Cy 18:GB4009. doi:10.1029/2004GB002238

Bastviken D, Santoro AL, Marotta H, Pinho LQ, Calheiros DF, Crill P, Enrich-Prast A (2010) Methane emissions from pantanal, South America, during the low water season: toward more comprehensive sampling. Environ Sci Technol 44:5450-5455

Bastviken D, Tranvik LJ, Downing JA, Crill PM, Enrich-Prast A (2011) Freshwater methane emissions offset the continental carbon sink. Science 331:50

Baulch HM, Schiff SL, Maranger R, Dillon PJ (2011) Nitrogen enrichment and the emission of nitrous oxide from streams. Glob Biogeochem Cy 25:GB4013. doi:10.1029/2011GB004047

Borges AV, Abril G, Delille B, Descy J-P, Darchambeau F (2011) Diffusive methane emissions to the atmosphere from Lake Kivu (Eastern Africa). J Geophys Res 116:G03032. doi:10.1029/ 2011JG001673

Borges AV, Bouillon S, Abril G, Delille B, Poirier D, Commarieu M-V, Lepoint G, Morana C, Champenois W, Servais P (2012) Variability of carbon dioxide and methane in the epilimnion of Lake Kivu. In: Descy JP, Darchambeau F, Schmid M (eds) Lake
Kivu-Limnology and biogeochemistry of a tropical great lake. Springer, New York London, pp 47-66

Borges AV, Morana C, Bouillon S, Servais P, Descy J-P, Darchambeau F (2014) Carbon cycling of Lake Kivu (East Africa): net autotrophy in the epilimnion and emission of $\mathrm{CO}_{2}$ to the atmosphere sustained by geogenic inputs. PLoS One 9:e109500

Borges AV, Darchambeau F, Teodoru CR, Marwick TR, Tamooh F, Geeraert N, Omengo FO, Guérin F, Lambert T, Morana C, Okuku E, Bouillon S (2015a) Globally significant greenhouse gas emissions from African inland waters. Nat Geosci 8:637-642

Borges AV, Abril G, Darchambeau F, Teodoru CR, Deborde J, Vidal LO, Lambert T, Bouillon S (2015b) Divergent biophysical controls of aquatic $\mathrm{CO}_{2}$ and $\mathrm{CH}_{4}$ in the World's two largest rivers. Sci Rep 5

Borrel G, Jézéquel D, Biderre-Petit C, Morel-Desrosiers N, Morel J-P, Peyret P, Fonty G, Lehours A-C (2011) Production and consumption of methane in freshwater lake ecosystems. Res Microbiol 162:832-847

Cole JJ, Caraco NF (1998) Atmospheric exchange of carbon dioxide in a low-wind oligotrophic lake measured by the addition of SF6. Limnol Oceanogr 43:647-656

Crowe S, Katsev S, Leslie K, Sturm A, Magen C, Nomosatryo S, Pack M, Kessler J, Reeburgh W, Roberts J (2011) The methane cycle in ferruginous Lake Matano. Geobiology 9:61-78

Darchambeau F, Sarmento H, Descy JP (2014) Primary production in a tropical large lake: the role of phytoplankton composition. Sci Total Environ 473-474:178-188

Degens ET, von Herzen RP, Wong H-K, Deuser WG, Jannasch HW (1973) Lake Kivu: structure, chemistry and biology of an East African rift lake. Geol Rundsch 62:245-277

Devol AH, Richey JE, Forsberg BR, Martinelli LA (1990) Seasonal dynamics in methane emissions from the Amazon River floodplain to the troposphere. J Geophys Res 95:16417-416426

Engle D, Melack JM (2000) Methane emissions from an Amazon floodplain lake: enhanced release during episodic mixing and during falling water. Biogeochemistry 51:71-90

Hofmann H (2013) Spatiotemporal distribution patterns of dissolved methane in lakes: how accurate are the current estimations of the diffusive flux path? Geophys Res Lett 40:2779-2784

Holgerson MA, Raymond PA (2016) Large contribution to inland water $\mathrm{CO}_{2}$ and $\mathrm{CH}_{4}$ emissions from very small ponds. Nat Geosci 9:222-226

İnceoğlu Ö, Llirós M, García-Armisen T, Crowe SA, Michiels C, Darchambeau F, Descy J-P, Servais P (2015a) Distribution of bacteria and archaea in meromictic tropical Lake Kivu (Africa). Aquat Microb Ecol 74:215-233

İnceoğlu Ö, Llirós $\mathrm{M}$, Crowe $\mathrm{S}$, García-Armisen $\mathrm{T}$, Morana $\mathrm{C}$, Darchambeau F, Borges A, Descy J-P, Servais P (2015b) Vertical distribution of functional potential and active microbial communities in meromictic Lake Kivu. Microb Ecol 70:596-611

IPCC (2013) Climate change: the physical science basis. Contribution of working group I to the fifth assessment report of the intergovernmental panel on climate change. United Kingdom, USA

Iversen N, Oremland RS, Klug MJ (1987) Big Soda Lake (Nevada). 3. Pelagic methanogenesis and anaerobic methane oxidation. Limnol Oceanogr 32:804-814

Kankaala P, Huotari J, Tulonen T, Ojala A (2013) Lake-size dependent physical forcing drives carbon dioxide and methane effluxes from lakes in a boreal landscape. Limnol Oceanogr 58:1915-1930

Kirschke S, Bousquet P, Ciais P, Saunois M, Canadell JG, Dlugokencky EJ, Bergamaschi P, Bergmann D, Blake DR, Bruhwiler L, Cameron-Smith P, Castaldi S, Chevallier F, Feng L, Fraser A, Heimann M, Hodson EL, Houweling S, Josse B, Fraser PJ, Krummel PB, Lamarque JF, Langenfelds RL, Le Quéré C, Naik 
V, O’Doherty S, Palmer PI, Pison I, Plummer D, Poulter B, Prinn RG, Rigby M, Ringeval B, Santini M, Schmidt M, Shindell DT, Simpson IJ, Spahni R, Steele LP, Strode SA, Sudo K, Szopa S, Van Der Werf GR, Voulgarakis A, Van Weele M, Weiss RF, Williams JE, Zeng G (2013) Three decades of global methane sources and sinks. Nat Geosci 6:813-823

Llirós M, Gich F, Plasencia A, Auguet JC, Darchambeau F, Casamayor EO, Descy JP, Borrego C (2010) Vertical distribution of ammonia-oxidizing crenarchaeota and methanogens in the epipelagic waters of lake kivu (Rwanda-Democratic Republic of the Congo). Appl Environ Microbiol 76:6853-6863

Marotta H, Pinho L, Gudasz C, Bastviken D, Tranvik LJ, Enrich-Prast A (2014) Greenhouse gas production in low-latitude lake sediments responds strongly to warming. Nature Clim Change $4: 467-470$

Melack JM, Hess LL, Gastil M, Forsberg BR, Hamilton SK, Lima IBT, Novo EMLM (2004) Regionalization of methane emissions in the Amazon Basin with microwave remote sensing. Glob Change Biol 10:530-544

Mengis M, Gächter R, Wehrli B (1997) Sources and sinks of nitrous oxide $\left(\mathrm{N}_{2} \mathrm{O}\right)$ in deep lakes. Biogeochemistry 38:281-301

Miettinen H, Pumpanen J, Heiskanen JJ, Aaltonen H, Mammarella I, Ojala A, Levula J, Rantakari M (2015) Towards a more comprehensive understanding of lacustrine greenhouse gas dynamics - two-year measurements of concentrations and fluxes of $\mathrm{CO}_{2}, \mathrm{CH}_{4}$ and $\mathrm{N}_{2} \mathrm{O}$ in a typical boreal lake surrounded by managed forests. Boreal Environ Res 20:75-89

Miranda KM, Espey MG, Wink DA (2001) A rapid, simple spectrophotometric method for simultaneous detection of nitrate and nitrite. Nitric Oxide Biol Chem 5:62-71

Morana C, Sarmento H, Descy JP, Gasol JM, Borges AV, Bouillon S, Darchambeau F (2014) Production of dissolved organic matter by phytoplankton and its uptake by heterotrophic prokaryotes in large tropical lakes. Limnol Oceanogr 59:1364-1375

Morana C, Darchambeau F, Roland FAE, Borges AV, Muvundja FA, Kelemen Z, Masilya P, Descy JP, Bouillon S (2015a) Biogeochemistry of a large and deep tropical lake (Lake Kivu, East Africa): insights from a stable isotope study covering an annual cycle. Biogeosciences 12:4953-4963

Morana C, Borges AV, Roland FAE, Darchambeau F, Descy JP, Bouillon S (2015b) Methanotrophy within the water column of a large meromictic tropical lake (Lake Kivu, East Africa). Biogeosciences 12:2077-2088

Natchimuthu S, Sundgren I, Gålfalk M, Klemedtsson L, Crill P, Danielsson $\AA$, Bastviken D (2015) Spatio-temporal variability of lake $\mathrm{CH} 4$ fluxes and its influence on annual whole lake emission estimates. Limnol Oceanogr. doi:10.1002/lno.10222

Nayar A (2009) Earth science: a lakeful of trouble. Nature News 460:321-323

Pasche N, Dinkel C, Muller B, Schmid M, Wuëst A, Wehrli B (2009) Physical and biogeochemical limits to internal nutrient loading of meromictic lake kivu. Limnol Oceanogr 54:1863-1873

Pasche N, Schmid M, Vazquez F, Schubert CJ, Wüest A, Kessler JD, Pack MA, Reeburgh WS, Bürgmann H (2011) Methane sources and sinks in Lake Kivu. J Geophys Res 116:G03006.doi:10. 1029/2011JG001690

Podgrajsek E, Sahlée E, Rutgersson A (2014) Diurnal cycle of lake methane flux. J Geophys Res Biogeosci 119:236-248

Polsenaere P, Deborde J, Detandt G, Vidal LO, Pérez MA, Marieu V, Abril G (2013) Thermal enhancement of gas transfer velocity of $\mathrm{CO} 2$ in an Amazon floodplain lake revealed by eddy covariance measurements. Geophys Res Lett 40:1734-1740

Read JS, Hamilton DP, Desai AR, Rose KC, MacIntyre S, Lenters JD, Smyth RL, Hanson PC, Cole JJ, Staehr PA (2012) Lake-size dependency of wind shear and convection as controls on gas exchange. Geophys Res Lett 39:L09405. doi:10.1029/ 2012GL051886

Riera JL, Schindler JE, Kratz TK (1999) Seasonal dynamics of carbon dioxide and methane in two clear-water lakes and two bog lakes in northern Wisconsin, USA. Can J Fish Aquat Sci 56:265-274

Saad OALO, Conrad R (1993) Temperature dependence of nitrification, denitrification, and turnover of nitric oxide in different soils. Biol Fertil Soils 15:21-27

Sawakuchi HO, Bastviken D, Sawakuchi AO, Krusche AV, Ballester MV, Richey JE (2014) Methane emissions from Amazonian Rivers and their contribution to the global methane budget. Glob Change Biol 20:2829-2840

Schilder J, Bastviken D, Hardenbroek M, Kankaala P, Rinta P, Stötter T, Heiri O (2013) Spatial heterogeneity and lake morphology affect diffusive greenhouse gas emission estimates of lakes. Geophys Res Lett 40:5752-5756

Schmid M, Wüest A (2012) Stratification, mixing and transport processes in Lake Kivu. In: Descy JP, Darchambeau F, Schmid M (eds) Lake Kivu: limnology and biogeochemistry of a tropical great lake. Springer, New York, London

Schmid M, Halbwachs M, Wehrli B, Wüest A (2005) Weak mixing in Lake Kivu: New insights indicate increasing risk of uncontrolled gas eruption. Geochem Geophys Geosyst 6:Q07009. doi:10. 1029/2004GC000892

Schmidt W (1928) Über die Temperatur- und Stabilitätsverhältnisse von Seen. Geogr Ann 10:145-177

Schubert CJ, Lucas F, Durisch-Kaiser E, Stierli R, Diem T, Scheidegger O, Vazquez F, Müller B (2010) Oxidation and emission of methane in a monomictic lake (Rotsee, Switzerland). Aquat Sci 72:455-466

Seitzinger S, Harrison JA, Böhlke JK, Bouwman AF, Lowrance R, Peterson B, Tobias C, Van Drecht G (2006) Denitrification across landscapes and waterscapes: a synthesis. Ecol Appl 16:2064-2090

Smith LK, Lewis WM Jr (1992) Seasonality of methane emissions from five lakes and associated wetlands of the Colorado Rockies. Glob Biogeochem Cy 6:323-338

Stahl DA, De La Torre JR (2012) Physiology and diversity of ammonia-oxidizing archaea. Annu Rev Microbiol 66:83-101

Stieglmeier M, Mooshammer M, Kitzler B, Wanek W, ZechmeisterBoltenstern S, Richter A, Schleper C (2014) Aerobic nitrous oxide production through $\mathrm{N}$-nitrosating hybrid formation in ammonia-oxidizing archaea. ISME J 8:1135-1146

Tassi F, Vaselli O, Tedesco D, Montegrossi G, Darrah T, Cuoco E, Mapendano MY, Poreda R, Delgado Huertas A (2009) Water and gas chemistry at Lake Kivu (DRC): geochemical evidence of vertical and horizontal heterogeneities in a multibasin structure. Geochem Geophys Geosyst 10:Q02005.doi:10.1029/2008GC002191

Thiery W, Martynov A, Darchambeau F, Descy JP, Plisnier PD, Sushama L, van Lipzig NPM (2014) Understanding the performance of the FLake model over two African Great Lakes. Geosci Model Dev 7:317-337

Weiss RF (1981) Determinations of carbon dioxide and methane by dual catalyst flame ionization chromatography and nitrous oxide by electron capture chromatography. J Chromatogr Sci 19:611-616

Weiss RF, Price BA (1980) Nitrous oxide solubility in water and seawater. Mar Chem 8:347-359

Westwood D (1981) Ammonia in waters (ed) Methods for the examination of waters and associated materials. HMSO, London

Winfrey M, Zeikus J (1979) Microbial methanogenesis and acetate metabolism in a meromictic lake. Appl Environ Microbiol $37: 213-221$

Xiao W, Liu S, Li H, Xiao Q, Wang W, Hu Z, Hu C, Gao Y, Shen J, Zhao X, Zhang M, Lee X (2014) A flux-gradient system for 
simultaneous measurement of the $\mathrm{CH}_{4}, \mathrm{CO}_{2}$, and $\mathrm{H}_{2} \mathrm{O}$ fluxes at a lake-air interface. Environ Sci Technol 48:14490-14498

Yamamoto S, Alcauskas JB, Crozier TE (1976) Solubility of methane in distilled water and seawater. J Chem Eng Data 21:78-80

Yvon-Durocher G, Allen AP, Bastviken D, Conrad R, Gudasz C, StPierre A, Thanh-Duc N, del Giorgio PA (2014) Methane fluxes show consistent temperature dependence across microbial to ecosystem scales. Nature 507:488-491

Zhang GL, Zhang J, Liu SM, Ren JL, Zhao YC (2010) Nitrous oxide in the Changjiang (Yangtze River) Estuary and its adjacent marine area: riverine input, sediment release and atmospheric fluxes. Biogeosciences 7:3505-3516 